\title{
Ekwiwalencja w translacji - tertium comparationis czy iluzja?
}

Equivalence in translation - tertium comparationis or illusion?

\author{
Anna MALGORZEWICZ \\ Uniwersytet Wrocławski/ University of Wrocław \\ E-mail: anna.malgorzewicz@uwr.edu.pl,
}

\begin{abstract}
The paper discusses issues connected with translation equivalence. The author reviews existing concepts of translation equivalence while paying particular attention to those falling within the paradigm of anthropocentric translation studies. The conducted research showed that this concept has evolved from being a static category to becoming a dynamic category. Translation invariants which are perceived as tertium comparationis in translation serve here as the focus of attention. Those include invariability of thematic reference and adequacy of communicative aim of translation. The ontological paradox understood as complementary coexistence of identity and difference is also discussed here. Another issue presents subjectivity perceived as immanent quality of cognitive and task-related activity of participants of translation communication which seems to challenge the objectivity of category of equivalence.
\end{abstract}

Keywords: translation equivalence, adequacy, invariant, ontological paradox of translation, collocutionality, coreferentiality

\section{Wierność versus wolność w tlumaczeniu}

Reflektowanie aspektów związanych z ekwiwalencją translacyjną ma swój początek w dyskusji dotyczącej metodyki thumaczenia, która stawia tłumacza przed trudnym wyborem pomiędzy wiernym i wolnym thumaczeniem. Zawarta w znanej powszechnie formule So wörtlich wie möglich und so frei wie nötig! obligacja zobowiązywała do zachowania formy wyjściowej oryginału. Jeśli autorstwo tej maksymy przypisać św. Hieronimowi, jak się powszechnie przyjmuje, takie stanowisko nie powinno dziwić. Św. Hieronim w odniesieniu do własnego thumaczenia Biblii przyznał, że sama kolejność słów stanowiła dla niego misterium (Ubi et verborum ordo mysterium est), któremu podporządkował swoją metodę thumaczeniową. Metoda tłumaczenia dosłownego lansuje prymat formy oryginału w odróżnieniu od tłumaczenia „wolnego" ukierunkowanego na thumaczenie sensów, stawiającego treść ponad formę ich werbalizacji.

Tłumaczenie wierne i wolne było postrzegane jako dwie dychotomiczne względem siebie metody translacyjne, jako usytuowane na dwóch przeciwległych biegunach obligacje translacyjne. Jak pokazują badania nad translacją, ich współistnienie w świadomości thumacza stanowi dla niego problem, z którym konfrontowany jest w każdym akcie translacji. 
W zależności od właściwej danej epoce politycznej i ideologicznej konstelacji można zaobserwować różne rozstrzygnięcia tego dylematu. I tak np. w średniowieczu domagano się scholastycznego, dosłownego tłumaczenia Biblii, któremu później przeciwstawił się Luter uznający sens a nie słowo za jednostkę thumaczeniową (por. M. Luther (1530/1973) Sendbrief vom Dolmetschen). I to właśnie kategoria, która została uznana za podstawę tłumaczenia, była traktowana jako obiekt porównań i ocen jakości tłumaczenia.

\section{Iluzoryczność ekwiwalencji translacyjnej}

F. Paepcke w swym eseistycznym artykule z 1981 r. pt. Die Illusion der Äquivalenz [Iluzja ekwiwalencji] starał się wykazać iluzoryczność ekwiwalencji translacyjnej podobnie jak później czynili to inni teoretycy translacji (np. M. Snell-Hornby 1986, 1988). W zasadzie trudno się dziwić, że do takiej konkluzji dochodzi zadeklarowany reprezentant nurtu hermeneutycznego. Właściwe dla tego paradygmatu odejście od zmaterializowanej formy tekstu i włączenie do rozważań dotyczących rozumienia tekstu kategorii nielingwistycznych oraz utożsamianie samej translacji z aktem przeżywania, doświadczania obcości - rozpatrywanej jako immanentnej właściwości każdego tekstu - musiało doprowadzić do podważenia potencjalnej ekwiwalentności rezultatów procesów interpretacyjnych ewokowanych przez tekst oryginału i tekst thumaczenia. Hermeneutyczne podejście do translacji, podobnie jak podejście relatywistów, eksponuje relację między myśleniem a językiem i, co się z tym wiąże, rozszerza lingwistycznie uwarunkowane ramy koncepcyjne i interpretacyjne kategorii ekwiwalencji. Akt rozumienia tekstu ukierunkowany jest bowiem według $\mathrm{F}$. Paepckego na rozpoznanie w tekstowych indykatorach tego, „,co pomyślane”. To, co pomyślane przez autora tekstu oryginału, jest w późniejszym etapie przedmiotem działań, operacji mentalnych i posunięć decyzyjnych tłumacza. Proces rozumienia tekstu utożsamiany jest $\mathrm{z}$ aktem stopniowego, sukcesywnego sterowania świadomością odbiorcy tegoż tekstu. Oczekiwanym efektem takiego aktu jest pozbawienie tekstu jego swoistej obcości, a tym samym uczynienie go zrozumiałym (F. Paepcke 1981/ 1986: 135).

\section{Identyczność i dyferencyjność w translacji - paradoks ontologiczny}

Za relewantne dla przedmiotu niniejszych rozważań uznałabym założenie Paepckego odnośnie do statusu ontologicznego ekwiwalencji translacyjnej. F. Paepcke (1981/1986: 143) uznaje, że identyczność zawsze istnieje w koegzystencji z dyferencyjnością, co oznacza, że to, co identyczne, współistnieje i definiuje się w relacji do innych jednostkowych identyczności (tożsamości). Dyferencyjność jest zatem konstytuentą identyczności. W konsekwencji tych twierdzeń należałoby przyjąć, że między tekstem a jego tłumaczeniem zachodzi jednocześnie relacja identyczności i dyferencyjności. Konieczność reflektowania tłumaczeń zarówno w kategoriach identyczności, jak i dyferencyjności, musi skutkować abnegacją całkowitej ekwiwalencji w thumaczeniu. Wydaje się to być logiczną konsekwencją - choćby z uwagi 
na różnice systemowe między językami, kulturami, kategorialne formy odmienności rzeczywistości, w których zakotwiczeni są uczestnicy komunikacji translacyjnej.

Ideę komplementarnego współistnienia identyczności i dyferencyjności w tłumaczeniu można by próbować koncepcyjnie rozwinąć w oparciu o koncepcję ,,paradoksu ontologicznego przekładu" sformułowaną przez D. Urbanek (2004: 45) na podstawie klasyfikacji sześciu ,paradoksów przekładu” T. H. Savory’ego (1957). Podstawowy paradoks przekładu upatruje D. Urbanek (2004: 45) w ,osiąganiu przez tłumacza skutków przeciwnych w stosunku do podejmowanych działań”, przy czym jako podstawowe działania tłumacza Badaczka określa (1) podporządkowanie artykulacji oryginału przekładowi, które dokonuje się, „właśnie paradoksalnie przez zachowanie elementów obcości w przekładzie" oraz (2) podporządkowanie przekładu oryginałowi, dążenie do bycia ,naturalnym w takim stopniu jak oryginał”, które „realizuje się poprzez zatarcie śladów oryginału” (Urbanek 2004: 45). Współistnienie wolności i wierności w translacji określa Urbanek terminem ontologia komplementarności $i^{1}$.

Koncepcja ontologii komplementarności wolności i wierności translacyjnej rozwinęła się w odpowiedzi na istniejące wcześniej, lingwistycznie ugruntowane, definicje ekwiwalencji translacyjnej, znajdując swoją koncepcyjna kontynuację w kognitywistycznie ugruntowanych ujęciach determinant translacyjnych. W spektrum naszych rozważań znajdą się wybrane koncepcje ekwiwalencji w ich chronologicznym uporządkowaniu, który ma odzwierciedlić rozwój myśli translatorycznej w zakresie badań nad ekwiwalencją translacyjną.

\section{Ekwiwalencja translacyjna w paradygmatach współczesnej translatoryki}

Spróbujmy zatem przyjrzeć się koncepcjom ekwiwalencji reprezentowanym w paradygmatach współczesnej translatoryki. Analiza diachroniczna teorii translatorycznych pozwala zaobserwować ewolucję ujęć statyczno-lingwistycznych (R. Jakobson 1959; J.C. Catford 1965) przez modele rozpatrujące ekwiwalencję na tle translacji definiowanej jako komunikacja (E.A. Nida/ Ch.R. Taber 1969; O. Kade 1968a, 1968b; K. Reiss/ H.J. Vermeer 1984; F. Grucza 1981, 1993, 1998; S. Grucza 2014; J. Żmudzki 2013, 2015), proces (również poznawczy) działanie i interakcja z otoczeniem (np. F. Grucza 1981, 1993, 1998; S. Grucza 2014; J. Żmudzki 2013, 2015; M. Vannerem/ M. Snell-Hornby 1986; H.J. Vermeer/ H. Witte 1990; P. Kußmaul 2010; H. Risku 2009; A. Małgorzewicz 2012)

\footnotetext{
${ }^{1}$ Należy zauważyć, że komplementarność wierności i wolności była postulowana również przez R. Jakobsona (1959) w jego koncepcji ekwiwalencji equivalence in difference. W później opublikowanej pracy (R. Jakobson 1992) widoczna jest zmiana podejścia R. Jakobsona do ekwiwalencji. Badacz używa innego określenia dla badanej kategorii, jakim jest Gleichwertigkeit in Verschiedenheit [równoważność w różności]. Podobne stanowisko reprezentuje M. Schreiber (1993, 1999, 2001), który zakłada, że thumaczenie powinno sprostać wymaganiom zarówno inwariancji, jak i wariancji (por. też Albrecht 1990, 2005).
} 


\begin{tabular}{|c|c|c|c|}
\hline & Od $\quad 1950-$ & $1960-\quad 1970-$ & $1980-$ \\
\hline & \multicolumn{3}{|c|}{ Obiektywizm -------------------------------------------------------Subiektywizm } \\
\hline $\begin{array}{l}\text { PRZEDMIOT } \\
\text { BADAŃ }\end{array}$ & Tekst & odbiorca/adresat tekstu & thumacz \\
\hline $\begin{array}{l}\text { DEFINICJA } \\
\text { TRANSLACJI }\end{array}$ & Transfer & komunikacja & $\begin{array}{l}\text { działanie / proces po- } \\
\text { znawczy }\end{array}$ \\
\hline $\begin{array}{l}\text { DOMINANTA } \\
\text { DZIAEAŃ } \\
\text { TRANSLA- } \\
\text { CYJNYCH } \\
\end{array}$ & Sens & funkcja komunikacyjna & $\begin{array}{l}\text { wolność/ kreatyw- } \\
\text { ność/podmiotowość } \\
\text { tłumacza }\end{array}$ \\
\hline $\begin{array}{l}\text { OBIEKT TER- } \\
\text { TIUM COM- } \\
\text { PARATIONIS } \\
\end{array}$ & $\begin{array}{l}\text { ekwiwalencja języ- } \\
\text { kowa }\end{array}$ & $\begin{array}{l}\text { ekwiwalencja komuni- } \\
\text { kacyjna }\end{array}$ & rozbieżność \\
\hline $\begin{array}{l}\text { STATUS } \\
\text { TŁUMACZA }\end{array}$ & \multicolumn{3}{|c|}{ thumacz niewidoczny --------------------------------------- thumacz widoczny } \\
\hline
\end{tabular}

Tabela 1. Ewolucja koncepcji translatorycznych (oprac. na podstawie T. Tomaszkiewicz 2008, G.L. Bastin/M.C. Cormier 2007).

\subsection{Ekwiwalencja językowa}

W początkowym stadium rozwoju badań translatorycznych translacja definiowana była w kategoriach transferu międzyjęzykowego. W centrum refleksji ówczesnych translatoryków był tekst oraz ekwiwalencja językowa, osiągana w wyniku operacji „przekodowywania” jednego kodu języka na kod drugiego języka (A.G. Oettinger 1960). Tłumaczenie definiowano jako zastępowanie elementów języka wyjściowego elementami języka docelowego. J.C. Catford (1965) rozpatrywał substytucję materiału tekstowego jednego języka na ekwiwalentny materiał tekstowy drugiego języka. Ekwiwalencja tekstowa analizowana była w odniesieniu do mniejszych lub większych fragmentów tekstów, w zależności od pary językowej na różnych poziomach struktury języka. J.C. Catford uznał, że badania ekwiwalentów tekstowych określonej pary językowej pozwalają na ustalenie prawdopodobieństwa ekwiwalencji translacyjnej. Zdefiniowanie przez J.C. Catforda tekstu jako kategorii weryfikującej ekwiwalentność jednostek języka należy uznać jako ważny krok w rozwoju refleksji nad translacją. Istotne w tym względzie było wyraźne rozgraniczenie ekwiwalencji translacyjnej od korespondencji formalnej, zachodzącej między odpowiednikami formalnymi, zdefiniowanymi jako kategorie zajmujące możliwie takie samo miejsce w ekonomii języka docelowego, jakie zajmuje dana kategoria w ekonomii języka źródłowego. Chodzi tutaj o jednakowość funkcji, które pełnią określone „fragmenty języka” źródłowego i docelowego w odnośnych systemach. Korespondencja formalna pozwala ustalić różnicę typologiczną między językami. Relacje te są według J.C. Catforda weryfikowalne również w oparciu o ekwiwalencje tekstową $^{2}$ (zob. A. Kizińska 2013: 17). Jednym z niezbędnych warunków zaistnienia

${ }^{2}$ Innym teoretykiem translacji, który kategorię ekwiwalencji rozpatruje na tle tekstu, był W. Wilss (1992). Relację ekwiwalencji pomiędzy tekstem wyjściowym i docelowym odnosi 
ekwiwalencji według J.C. Catforda (1965) jest inwariancja referencjalna, czyli odsyłanie za pomocą tekstu wyjściowego i docelowego do jednej i tej samej rzeczy.

Ujęcie ekwiwalencji oparte na porównaniach systemów języków (par językowych), uzupełnione o inne obszary jej odniesień, proponuje W. Koller (1979/2007) w powszechnie znanej książce Einführung in die Übersetzungswissenschaft. W. Koller (1979/2007: 214-266) rozróżnia pięć typów ekwiwalencji, przyporządkowując im jednocześnie właściwe dla nich obszary odniesienia. Najprawdopodobniej opierając się na tej typologii J. Pieńkos (2003: 176 i n.) definiuje pięć rodzajów „referencyjności”, które odgrywają ,istotną rolę przy ustalaniu typów ekwiwalencji. Są nimi rzeczywistość pozajęzykowa (ekwiwalencja denotatywna), występujący w tekście rodzaj werbalizacji (ekwiwalencja konotatywna), normy tekstowe i językowe (ekwiwalencja tekstowo-normatywna), odbiorca (czytelnik) (ekwiwalencja pragmatyczna (W. Koller)/ pragmatyczna lub komunikatywna (J. Pieńkos)) oraz właściwości estetyczne, formalne (ekwiwalencja formalno-estetyczna (W. Koller)/ ekspresywna lub artystyczno-estetyczna (J. Pieńkos)). Niestety W. Koller nie czyni ustaleń w odniesieniu do kryteriów, zaleceń, według których tłumacz miałaby kierować się w prospektywnym wyborze określonego typu ekwiwalencji. Bez odpowiedzi pozostaje kwestia hierarchicznego uporządkowania wyróżnionych typów ekwiwalencji, mimo że powołując się R.W. Jumpelta (1961) W. Koller (1979/2007: 266) pośrednio sygnalizuje konieczność ustalenia hierarchii wartości, które powinny być zachowane w tłumaczeniu. W koncepcji W. Kollera odnajdujemy postulat osiągnięcia „maksymalnej” ekwiwalencji, niestety jej autor nie precyzuje, do jakich skal stopniowalności (?), wielkości (?), kategorii (?) się odnosi.

\subsection{Ewiwalencja komunikacyjna}

Kolejnym ważnym zwrotem w badaniach nad ekwiwalencją było wprowadzenie kategorii ekwiwalencji dynamicznej osiąganej w wyniku transferu na poziomie struktur głębokich języka. Transfer ten dokonuje się według E.A. Nidy i Ch.R. Tabera (1969) pomiędzy etapem analizy tekstu wyjściowego i etapem syntezy skutkującej reprodukcją tekstu docelowego. Znalezienie najbliższych ekwiwalentów naturalnych komunikatu źródłowego umożliwia osiągnięcie ekwiwalentnego efektu komunikacyjnego.

Podobnie jak E.A. Nida i Ch.R. Taber (1969) również reprezentanci Szkoły Lipskiej postulują zobowiązanie tłumacza do osiągnięcia ekwiwalencji na poziomie komunikacji, co według O. Kadego (1968b: 11) możliwe jest tylko przy zachowaniu inwariancji denotatywnej (por. inwariancja referencjalna u J.C. Catforda 1965).

W. Wilss do sytuacji, gdy do poszczególnych elementów tekstu wyjściowego można odnaleźć odpowiedniki 1:1 w języku docelowym. Tłumaczenie niedosłowne traktuje W. Wilss jako wyjątek, do którego tłumacz ucieka się w sytuacji, gdy brakuje odpowiedników 1:1 na płaszczyźnie systemowej języków i płaszczyźnie konwencji specyficznych genologicznie (W. Wilss 1992: 64). Określanie niedosłownego tłumaczenia w kategoriach wyjątku nie może spotkać się z akceptacją - podobnie jak założenie W. Wilssa (1992: 64), iż tłumaczenia dosłowne - w odróżnieniu od niedosłownych - nie są konsekwencją decyzji tłumacza a mechanicznym przejęciem odpowiednika 1:1. 
Uznając ekwiwalencję wartości komunikacyjnej danego tekstu za inwariant translacji, O. Kade (1968b) wskazuje zasadnie na wynikające $\mathrm{z}$ tej pozajęzykowej determinacji trudności w jej definiowaniu. Komunikatywną wartość tekstu można bowiem ustalić na podstawie jego relacji do intencji nadawcy tekstu wyjściowego, co w opinii O. Kadego jest niemożliwe ze względu na brak uchwytnych wskaźników intencji w tekście. Są one ulokowane w świadomości użytkownika języka (O. Kade 1968b: 9). Istotne w koncepcji O. Kadego jest utożsamianie wartości komunikacyjnej z zawartością informacyjną tekstu realizującego określone intencje jego nadawcy. Konsekwencją tego założenia jest odniesienie warunku zaistnienia efektywnej komunikacji translacyjnej do zachowania ekwiwalencji na poziomie treści tekstu. Jednostkę thumaczenia definiuje O. Kade (1968a: 90) jako „najmniejszy segment tekstu w języku wyjściowym, który dzięki potencjalnym relacjom ekwiwalencji może być zastąpiony segmentem tekstu $\mathrm{w}$ języku docelowym spełniającym warunek inwariancji na poziomie treści". J. Żmudzki (1991: 46) wykazuje, że z czasem O. Kade (1980) zweryfikował swoje stanowisko, lokując ekwiwalencję komunikacyjną na płaszczyźnie relacji między komunikatem i sytuacją komunikacyjną, jednocześnie definiując jej właściwe inwarianty jako właściwości tekstów, odpowiadające relacjom między komunikatem a sytuacją.

Komunikacyjna determinanta translacji uznana jest za obowiązującą również w funkcjonalnej teorii Skoposu. Dla K. Reiß i H.J. Vermeera (1984: 170) ekwiwalencja jest „dynamicznym pojęciem określającym relację między tekstem wyjściowym i docelowym, która w przypadku każdego tekstu (oraz każdego jego elementu składającego się na sens i funkcję całego tekstu) wymaga nowego (sobie właściwego - A.M.) uporządkowania ważności tych czynników, które mają wpływ na proces thumaczenia". Owego uporządkowania thumacz dokonuje stosując operacje selekcji i hierarchizacji relewantnych dla komunikacji translacyjnej czynników. Relacja translacyjnej ekwiwalencji między tekstem wyjściowym a docelowym może zaistnieć w myśl koncepcji K. Reiß i H.J. Vermeera (1984: 170) wskutek stworzenia „funkcjonalnie równoważnych relacji między treściami i formami tekstu wyjściowego i docelowego w ich funkcji tworzenia sensu dla określonego tekstu". Operacje tłumacza podporządkowane są regule koherencji, według której translację można uznać za udaną pod warunkiem, że translat $\mathrm{w}$ ocenie jego odbiorcy jest interpretowalny, zrozumiały. Reguła ta zobowiązuje tłumacza do neutralizacji poznawczo obcych dla odbiorcy translatu elementów tekstu wyjściowego, a tym samym uprzedniej identyfikacji jego możliwości recepcyjnych. Postulaty reprezentantów teorii skoposu przeciwstawiają się formule św. Hieronima, wzywają wręcz do wolności w świadomym, autonomicznym działaniu podporządkowanym komunikacyjnym intencjom.

\subsection{Ekwiwalencja na poziomie konceptualizacji i obrazowania}

Starania tłumacza zorientowane na zapewnienie powodzenia komunikacyjnego w myśl najbardziej aktualnych koncepcji ukierunkowane są na stworzenie tekstu dostosowanego do możliwości percepcyjnych, recepcyjnych i interpretacyjnych jego adresata. I tak obecny w badaniach nad translacją, wspomniany wcześniej, nurt ko- 
gnitywistyczny pozwala traktować tłumacza i inne podmioty poznawcze biorące udział w komunikacji translacyjnej jako konceptualizatorów (por. W.J.M. Levelt 1989; R. Dirven/ G. Radden 2003; R. Dirven/ G. Radden/ E. Tabakowska 2001; E. Tabakowska 1993/2001; A. Małgorzewicz 2009, 2010, 2012) a teksty w niej komunikacyjnie instrumentalizowane jako wynik zdeterminowanych kulturowo konceptualizacji. I to właśnie obrazowanie, konceptualizacje czy też ,rekonceptualizacje w procesie emergencji znaczeń dyskursywnych" (B. Lewandowska-Tomaszczyk 2010: 28) czyni się przedmiotem ukierunkowanych działań tłumacza ${ }^{3}$. Są one płaszczyzną, którą wskazuje się jako możliwy, aczkolwiek niekonieczny, obszar wartości niezmiennych $\mathrm{w}$ translacji.

W nurcie kognitywistycznym badań translatorycznych rozpowszechniona jest teoria metafory konceptualnej i kognitywna semantyka ram i scen Ch.J. Fillmora (1977) (np. M. Vannerem/ M. Snell-Hornby 1986, H.J. Vermeer/ H. Witte 1990, E.N. Kurth 1994; E. Tabakowska 1993/2001, P. Kußmaul 2010, A. Małgorzewicz 2009, 2010). Paradygmat ten akcentuje rolę wiedzy, doświadczenia, uwikłania kulturowego oraz konieczność kreatywnych rozwiązań w konstruowaniu znaczeń $\mathrm{w}$ procesach rozumienia i tworzenia tekstu. W tym względzie zdolnościom poznawczym przypisuje się zasadniczą rolę. Płaszczyznę porównania i oceny tekstu tłumaczenia stanowią konceptualizacje, sceny kognitywne aktywizowane w umysłach uczestników komunikacji translacyjnej. E. Tabakowska (1993/2001: 161) nawiązując do R.A. Beagrande’a i W. Dresslera (1981) postuluje ekwiwalencję w doświadczeniu, mając na myśli płaszczyznę recepcji tekstu. Jednocześnie Badaczka zauważa (E. Tabakowska 1993/2001: 162), że różnice w zakresie zdolności poznawczych i pojęciowych nie są przeszkodami na drodze do osiągnięcia ekwiwalencji w tłumaczeniu. Przeszkodami są natomiast zawsze różnice systemowe. Mówiąc o kognitywnie zorientowanych badaniach nad translacją nie można w tym w miejscu nie wspomnieć o warszawskim badaczu O. Wojtasiewiczu, który już w 1957 r. postulował zachowanie ekwiwalencji na poziomie skojarzeń: „Operacja tłumaczenia tekstu a sformułowanego w języku A na język B polega na sformułowaniu tekstu b w języku B, który to tekst b wywołałby u jego odbiorców skojarzenia takie same lub bardzo zbliżone do tych, które u odbiorców wywołał tekst A" (O. Wojtasiewicz 1957: 28).

\section{W poszukiwaniu inwariantów translacyjnych - kollokucyjność i koreferen- cyjność w translacji}

Koncepcją, która łączy właściwości procesów poznawczych uczestników komunikacji translacyjnych z ich komunikacyjnym, kulturowym i językowym uwikłaniem jest antropocentryczny model translacji, którego twórcą jest F. Grucza (1981, 1993, 1998). Model ten został w późniejszym stadium badań koncepcyjnie rozszerzony przez J. Żmudzkiego (2013, 2015). Istotną, nową kategorią w tym modelu jest zada-

\footnotetext{
${ }^{3}$ Kognitywiści rozpatrują ekwiwalencję translacyjną na poziomie obrazowania. Należy jednak zauważyć, że metoda ta najlepiej sprawdza się w przypadku analizy thumaczeń literackich.
} 
nie translacyjne, którego parametry mają zasadniczy wpływ na sformułowanie przez thumacza celu komunikacji translacyjnej, realizowanej za pomocą translatu adresowanego do skonkretyzowanego odbiorcy. Zakłada się w tym modelu, że tłumacz chcąc osiągnąc komunikacyjny cel translacyjny, musi w swych posunięciach translacyjnych uwzględnić predyspozycje poznawcze adresatów tekstów tłumaczenia, ich oczekiwania komunikacyjne, uwikłanie kulturowe i sytuacyjne. J. Żmudzki akcentuje konieczność prospektywnego zorientowania translacji na tekst docelowy i traktowania tekstu wyjściowego jako „oferty informacyjnej” (por. K. Reiß/ H.J. Vermeer 1984), która w efekcie translacji będzie dostosowana do komunikacyjnego celu translacji i do możliwości recepcyjnych adresata translatu. J. Żmudzki (2014) wprowadza w związku z powyższym założeniem kategorię kollokucyjności rozumianej jako kompatybilność celów komunikacyjnych uczestników komunikacji translacyjnej. Innym obszarem postulowanej wierności jest koreferencyjność rozumiana jako wspólne, globalne odniesienie oryginału i translatu do świata sygnalizowanego na płaszczyźnie semantycznej tekstu wyjściowego. Podstawą pojęcia koreferencyjność jest kategoria stałości referencji tematycznej (J. Żmudzki 2014; por. Konstanz O. Kade 1968a). Zabiegi translacyjne mają na celu zachowanie ciągłości tekstu wyjściowego w tekście docelowym pod względem referencji tematycznej, a dalej również pod względem funkcjonalnym (tzn. tekst docelowy powinien zafunkcjonować jako narzędzie komunikacji z adresatem docelowym w zakresie realizacji określonego celu translacji realizowanego przez tłumacza), co uaktywnia z kolei kategorię adekwatności (J. Żmudzki 2014; por. Adäquatheit K. Reiß/ H.J. Vermeer 1984; J. Albrecht 1990, 2005). Imperatywem działań translacyjnych jest zapewnienie ciągłości tekstu wyjściowego w komunikacji docelowej.

Przyjmując założenia rozszerzonego modelu translacji w ujęciu Żmudzkiego, za determinantę działań translacyjnych należałoby uznać nie identyczność czy jednakowość tekstową, ale równoważność lub raczej kompatybilność w obszarze ów komunikacyjnych zdefiniowanych każdorazowo dla określonej sytuacji translacyjnej. Stałość referencji tematycznej i adekwatność względem celu translacji można by uznać za tertium comparationis translacji.

\section{Konkluzje}

Przedstawione w dużym skrócie wyniki analizy ujęć ekwiwalencji translacyjnej w poszczególnych koncepcjach translatorycznych pozwalają stwierdzić ewolucję kategorii statycznej odnoszącej się do systemów języków do zdynamizowanej kategorii wykraczającej poza system języka, ukonstytuowanej w wyniku wzajemnych relacji czynników aktywizowanych w obszarze komunikacji i mentalnych sfer jej uczestników. Istotny wydaje się formułowany przez teoretyków translacji wymóg rozpatrywania ekwiwalencji najmniejszych jednostek znaczeniowych w kontekście tekstu. Taki wymóg należałoby również sformułować w odniesieniu do rozpatrywania aktu mowy, illokucji manifestowanych przez ich wykładniki tekstowe. W rozpatrywaniu relacji ekwiwalencji tekst - rozumiany jako instrument komunikacji translacyjnej - należałoby uznać za podstawową jednostkę tłumaczeniową. Pierwszoplanową obligacją formułowaną wobec tłumacza powinno być zapewnienie ciągłości 
tekstu wyjściowego w komunikacji docelowej. Należy przyjąć, że komunikacja prymarna ma swoją kontynuację w komunikacji zapośredniczonej, nawet jeśli narzędzie komunikacyjne (tekst) zmieniło swoje właściwości, nawet jeśli ta komunikacja realizuje odmienne cele komunikacyjne, podporządkowane oczekiwaniom komunikacyjnym inicjatora translacji i adresata translatu, nawet jeśli komunikat adresowany jest do innej grupy odbiorców niż tekst wyjściowy. Zapewnienie owej ciągłości komunikacyjnej, adekwatna dyskursywno-sytuacyjna aktywizacja sensów $\mathrm{w}$ systemie mentalnym adresata tekstu jest możliwa nawet w przypadku istnienia różnic w sposobach konceptualizacji rzeczywistości, z którą tekst wyjściowy i docelowy występują w stosunku referencyjnym.

Tłumacz w swoich działaniach translacyjnych musi wyjść poza struktury języka, poza ekwiwalencję formalną postulowaną w modelach ugruntowanych lingwistycznie. W odniesieniu do najmniejszych jednostek thumaczeniowych należy przyjąć, że semantyczna forma zleksykalizowanego wyrażenia językowego osadzonego w określonym kontekście sytuacyjnym dopiero w wyniku ekstensji aktywizuje struktury konceptualne umożliwiające semantyczną interpretację. Pytanie, na które powinien odpowiedzieć tłumacz, nie brzmi zatem: Jakimi wyrażeniami języka docelowego powinienem zastąpić wyrażenia języka wyjściowego, a Jakie struktury konceptualne powinienem aktywizować w systemie mentalnym odbiorcy tekstu docelowego i za pomocą jakich wyrażeń języka docelowego mogę ten cel osiągnąć?

Zanim tłumacz skieruje swoją aktywność poznawczą na aktywizowanie znaczeń (sensów) najmniejszych jednostek tłumaczeniowych, powinien uprzednio ustalić hierarchiczny porządek inwariantów komunikacyjnych w ich kategorialnej specyfice i wzajemnym zdeterminowaniu, by z kolei w późniejszym etapie swych działań móc osiągnąć kollokucyjność translacyjną rozumianą jako kompatybilność celów komunikacyjnych wszystkich uczestników komunikacji translacyjnej, łącznie z inicjatorem translacji. Drugą obligacją formułowaną wobec tłumacza powinno być zachowanie stałości referencji tematycznej tekstu wyjściowego osiąganej za pomocą w tekstu docelowego. Dopiero na podstawie ustaleń wynikających z tych dwóch fundamentalnych zobowiązań można określić obszary kognitywne elementów znaczeniowych występujących $\mathrm{w}$ instrumentalizowanych translacyjnie tekstach. I w tych zakresach poznawczych powinna być lokowana ekwiwalencja translacyjna, rozpatrywana $w$ relacji do zmaterializowanych, tekstowych (nie mniejszych) realizacji językowych. Obligacja do zachowania ciągłości tematycznej tekstu wyjściowego w tekście docelowym nie wyklucza modyfikacji w zakresie właściwości lingwistycznych tekstu wyjściowego (por. ontologia komplementarności). Właściwości lingwistyczne nie mogą być główną determinantą działań translacyjnych. Nie mogą być również prymarnym obiektem tertium comaparationis.

Kategorię ekwiwalencji translacyjnej w prezentowanym ujęciu zastępuje kategoria inwariantu translacyjnego. Inwarianty translacyjne - definiowane jednostkowo dla każdej sytuacji translacyjnej - tworzą specyficzny, niepowtarzalny, hierarchicznie uporządkowany kompleks właściwości pozatekstowych i tekstowych (por. M. Schreiber 1999). Rangę pierwszoplanowych inwariantów uzyskują kategorie składające się na kollokucyjność i koreferencyjność translacyjną. Drugoplanowe 
inwarianty odnoszą się do właściwości tekstowych. Tłumacz w oparciu o te ustalenia konstruuje swą strategię translacyjną, której zastosowanie w działaniach translacyjnych ma doprowadzić do osiągnięcia celu translacyjnego.

Antropocentryzm zaprezentowanego podejścia do kwestii ekwiwalencji translacyjnej znosi obiektywność tej kategorii. Czynnik ludzki determinujący translacyjną komunikację na każdym jej poziomie i w każdym obszarze aktywności poznawczej jej uczestników podważa status ekwiwalencji znaczeniowej traktowanej jako obiektywne tertium comparationis. Akceptacji wymaga natomiast subiektywność rozumiana jako immanentna właściwość działań translacyjnych i poznawczych aktywności uczestników komunikacji translacyjnej, mających swe wykładniki w materialnych realizacjach tekstowych. Poszłabym nawet krok dalej i w ramach ujęć ontologicznych rzeczywistości translacyjnej uznałabym nadrzędność subiektywizmu wobec obiektywizmu. Aspekt tej nadrzędności powinien być włączony w spektrum zagadnień rozpatrywanych w kontekście działań translacyjnych (w ich retro- i prospektywnym zorientowaniu) na różnych ich poziomach, ich oceny i weryfikacji oraz w kontekście translodydaktyki. Ów subiektywizm należałoby respektować również przy ustalaniu inwariantów translacyjnych.

\section{Bibliografia}

Albrecht, J. (1990), Invarianz, Äquivalenz, Adäquatheit, (w:) E. Arntz/ G. Thome (red.), Übersetzungswissenschaft. Ergebnisse und Perspektiven. Festschrift für Wolfram Wilss zum 65. Geburtstag. Tübingen, 71-81.

Albrecht, J. (2005), Übersetzung und Linguistik. Tübingen.

Bastin, G.L./ M.C. Cormier (2007), Traducteur. Montréal.

Catford, J.C. (1965), A Linguistic Theory of Translation. An Essay in Applied Linguistics. London.

Dirven, R./ G. Radden (2003), Die kognitive Grundlage der Sprache, (w:) R. Pörings/ U. Schmitz (red.), Sprache und Sprachwissenschaft. Eine kognitiv orientierte Einführung. Tübingen, 5-30.

Dirven, R./ G. Radden/ E. Tabakowska (2001), Kognitywne podstawy jezzka, (w:) E. Tabakowska (red.), Kognitywne podstawy języka i językoznawstwa. Kraków, $15-44$.

Beaugrande, de R.A. / W. Dressler (1981), Einführung in die Textlinguistik. Tübingen.

Fillmore, Ch.J. (1977), Frames-and-scenes semantics, (w:) A. Zampolli (red.), Linguistic Structures Processing. Amsterdam, 55-81.

Grucza, F. (1981), Zagadnienia translatoryki, (w:) F. Grucza (red.), Glottodydaktyka a translatoryka. Warszawa, 9-29.

Grucza, F. (1993), Interkulturelle Translationskompetenz: ihre Struktur und Natur, (w:) F.A. Paul/ K.J. Maaß/ P. Fritz/ H. Turk (red.), Übersetzen, verstehen, Brücken bauen. Geisteswissenschaftliches und literarisches Übersetzen im internationalen Kulturaustausch. Berlin, 158-171.

Grucza, F. (1998), Wyodrębnienie się, stan aktualny i perspektywy świata translacji oraz translatoryki, (w:) „Lingua legis” 6, 2-12. 
Grucza, S. (2014), Grundzüge der anthropozentrischen Translatorik, (w:) A. ŁypBielecka (red.), Mehr als Worte. Sprachwissenschaftliche Studien. Professor Dr. Habil. Czesława Schatte und Professor Dr. Habil. Christoph Schatte gewidmet. Katowice, 127-137.

Jakobson, R. (1959), On Linguistic Aspects of Translation, (w:) R.A. Brower (red.), On Translation. Cambridge/ Mass, 232-239

Jakobson, R. (1992), Semiotik. Ausgewählte Texte 1919-1982. Frankfurt.

Jumpelt, R.W. (1961), Die Übersetzung naturwissenschaftlicher und technischer Literatur. Sprachliche Maßstäbe und Methoden zur Bestimmung ihrer Wesenszüge und Probleme. Berlin-Schönberg.

Kade, O. (1968a), Zufall und Gesetzmäßigkeit in der Übersetzung. Leipzig.

Kade, O. (1968b), Kommunikationswissenschaftliche Probleme der Translation, (w:) A. Neubert (red.), Grundfragen der Übersetzungswissenschaft. Leipzig, 3-19.

Kizińska, A. (2015), Ekwiwalencja w tłumaczeniu tekstów prawnych i prawniczych. Warszawa.

Koller, W. (1979/72004), Einführung in die Übersetzungswissenschaft. Wiebelsheim.

Kurth, E.-N. (1994), Metaphernübersetzung: dargestellt an grotesken Metaphern im Frühwerk Charles Dickens in der Wiedergabe deutscher Übersetzungen. Frankfurt am Main etc.

Kußmaul, P. ( $\left.{ }^{2} 2010\right)$, Verstehen und Übersetzen. Ein Lehr- und Arbeitsbuch. Tübingen.

Levelt, W.J.M. (1989), Speaking: From Intention to Articulation. Cambridge/ Mass.

Lewandowska-Tomaszczyk, B. (2010), Nowe spojrzenie na przekład: podobieństwo, granice ekwiwalencji i rekonceptualizacji, (w:) „Lingwistyka Stosowana/ Applied Linguistics/ Angewandte Linguistik" 3, 9-31.

Luther, M. (1530/1973), Sendbrief vom Dolmetschen, (w:) H.J. Störig (red.), Das Problem des Übersetzens. Darmstadt, 14-32.

Małgorzewicz, A. (2009), Metaphorische Konzeptualisierung von Angst-Emotionen und ihre Übersetzbarkeit dargestellt am Beispiel ausgewählter polnischer und deutscher Phraseologismen, (w:) W. Kunicki/ J. Rzeszotnik/ E. Tomiczek (red.), Breslau und die Welt: Festschrift für Prof. Dr. Irena Światłowska-Prędota zum 65. Geburtstag. Wrocław, 573-584.

Małgorzewicz, A. (2010), Bilder menschlicher Gefühle in der polnischen und deutschen Phraseologie und ihre Übersetzbarkeit, dargestellt am Beispiel der HerzMetapher in "Pan Tadeusz" von Adam Mickiewicz, (w:) P. Bąk/ M. Sieradzka/ Z. Wawrzyniak (red.), Texte und Translation. Frankfurt am Main etc., 121-132.

Małgorzewicz, A. (2012), Die Kompetenzen des Translators aus kognitiver und translationsdidaktischer Sicht. Wrocław.

Nida, E.A. / Ch.R. Taber (1969), The Theory and Practice of Translation. Leiden.

Oettinger, A.G. (1960), Automatic Language Translation. Lexical and Technical Aspects, with Particular Reference to Russian. Cambridge/ Mass.

Paepcke, F. (1981/1986), Die Illusion der Äquivalenz, (w:) E. Grötzinger/ A. Lawaty (red.), Suche die Meinung. Karl Dedecius dem Übersetzer und Mittler zum 65. Geburtstag. Wiesbaden, 116-151.

Pieńkos, J. (2003), Podstawy przekładoznawstwa. Od teorii do praktyki. Kraków. 
Reiß, K./ H.J. Vermeer (1984), Grundlegung einer allgemeinen Translationstheorie. Tübingen.

Risku, H. (2009), Translationsmanagement. Interkulturelle Fachkommunikation im Informationsalter. Tübingen.

Savory, T.H. (1957), The Art of Translation. London.

Schreiber, M. (1993), Übersetzung und Bearbeitung. Zur Differenzierung und Abgrenzung des Übersetzungsbegriffs. Tübingen.

Schreiber, M. (1999), Von der rechten und der linken Grenze der Übersetzung, (w:) N. Greiner/ J. Kornelius/ G. Rovere (red.), Texte und Kontexte in Sprachen und Kulturen. Festschrift für Jörn Albrecht. Trier, 269-279.

Schreiber, M. (2001), Translation (Traduction et interprétation), (w:) G. Holtus/ M. Metzeltin/ Ch. Schmitt (red.), Lexikon der Romanistischen Linguistik. Tübingen, 107-146.

Snell-Hornby, M. (1986), Übersetzen, Sprache, Kultur, (w:) M. Snell-Hornby (red.), Übersetzungswissenschaft. Eine Neuorientierung. Tübingen, 9-29.

Snell-Hornby, M. (1988), Translation Studies. An Integrated Approach. Amsterdam, Philadelphia.

Tabakowska, E. (1993/2001), Językoznawstwo kognitywne a poetyka przekładu. Kraków. [tłum. Agnieszka Pokojska]

Tomaszkiewicz, T. (2008), Dokąd zmierza współczesna translatoryka? (w:) K. Myczko/ B. Skowronek/ W. Zabrocki (red.), Perspektywy glottodydaktyki i językoznawstwa. Tom jubileuszowy z okazji 70. urodzin Profesora Waldemara Pfeifera. Poznań, 311-324.

Urbanek, D. (2004), Pęknięte lustro. Tendencje w teorii i praktyce przekładu na tle myśli humanistycznej. Warszawa.

Vannerem, M./ M. Snell-Hornby (1986), Die Szene hinter dem Text: 'scenes-andframes-semantics' in der Übersetzung, (w:) M. Snell-Hornby (red.), Übersetzungswissenschaft - Eine Neuorientierung zur Integrierung von Theorie und Praxis. Tübingen, 194-205.

Vermeer, H.J./ H. Witte (1990), Mögen Sie Zistrosen? Scenes \& frames \& channel im translatorischen Handeln. Heidelberg.

Wilss, W. (1992), Übersetzungsfertigkeit. Annäherungen an einen komplexen übersetzungspraktischen Begriff. Tübingen.

Wojtasiewicz, O. (1957/42005), Wstęp do teorii ttumaczenia. Warszawa.

Żmudzki, J. (1991), Zum Problem der bilingualen Äquivalenz lexikalischer Einheiten (Polnisch-Deutsch). Lublin.

Żmudzki, J. (2013), Holizm funkcjonalny $w$ perspektywie translatoryki antropocentrycznej, (w:) „Lingwistyka Stosowana/ Applied Linguistics/ Angewandte Linguistik" $8,177-187$.

Żmudzki, J. (2014), ,so treu, wie möglich, so frei, wie nötig“ - eine alte Translationsmaxime neu interpretiert, (w:) A. Lyp-Bielecka (red.), Mehr als Worte. Sprachwissenschaftliche Studien. Professor Dr. Habil. Czesława Schatte und Professor Dr. Habil. Christoph Schatte gewidmet. Katowice, 345-360.

Żmudzki, J. (2015), Blattdolmetschen in paradigmatischer Perspektive der anthropozentrischen Translatorik. Frankfurt am Main etc. 